\title{
RESTORING THE STALINGRAD REGION: PECULIARITIES OF USING STATE AND ORGANISING, FINANCIAL AND CREDIT RESOURCES OF THE USSR IN 1943-1944
}

\author{
Tatyana V. Lokhova \\ Novorossiysk Branch of Financial University under the Government of the Russian Federation, \\ Novorossiysk, Russian Federation \\ Elena M. Malysheva \\ Adyghe State University, Maikop, Russian Federation
}

\begin{abstract}
Historical experience in the Great Patriotic War and analysis of the main events, such as "the radical turn" and the battle for Stalingrad, are relevant to researchers not only due to anniversary of the War but also because of ongoing projects of unprecedented scale. Peculiarities of management and definition of economic, social and political resources used for recovery of the damage caused by hostilities and occupation of USSR is of academic interest.

The article is devoted to studying the organization of goal-orientated credit programs on restoration in 19431944 in the post-ocupation period. The author analyses the work of the USSR bank system in providing loans for restoring the agricultural potential of the region, and also implementing social policies for securing all categories of agrarian population. Work of credit institutions played a great part not only in restoring of agricultural production, but also in providing a real assistance to all farm buildings destroyed during the Great Patriotic War and to individual agricultural sector on the whole.

Restoration of the Stalingrad region is examined in the light of using state and organising, financial and credit, moral and patriotic resources of the USSR in 1943-1944. In order to overcome the consequences of occupation, additional state financing was required, which was used to restore some strategically significant institutions, to reevacuate some industrial equipment, to increase the number of cattle, to return specialists and to accomodate them, to create industrial infrastructure, to rebuild demolished buildings and so on. Methods and means used to gain the set goals were various: from well-organised government institutions to stupendous participation of the nation in different actions by national input, war loans and taxes. Taking under consideration the chronically shortage of state budget, the government relied on local initiatives towards raising money from hinterland. Restoring economic, social and cultural aspects of liberated areas was a matter of national importance that united different nationalities of the USSR.

T.V. Lokhova studies the objectives of monetary and credit policy, shows a positive experience of functioning of the National Bank and the Agricultural Bank of the USSR, which in the conditions of the mobilization economy $\infty$ combined the objectives of monetary policy. E.M. Malysheva conducts a historiographic review of modern academic research to identify the specifics of the activities of the bodies of Soviet power in the critical conditions of the

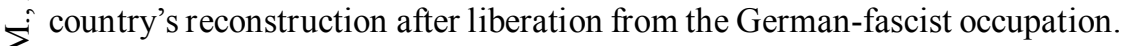

Key words: Great Patriotic War, economy restoration, credit programs, loan, National Bank of the USSR, Agricultural Bank of the USSR, Stalingrad, Stalingrad region.

Citation. Lokhova T.V., Malysheva E.M. Restoring the Stalingrad Region: Peculiarities of Using State and Organising, Financial and Credit Resources of the USSR in 1943-1944. Vestnik Volgogradskogo gosudarstvennogo universiteta. Seriya 4, Istoriya. Regionovedenie. Mezhdunarodnye otnosheniya [Science Journal of Volgograd State University. History. Area Studies. International Relations], 2018, vol. 23, no. 1, pp. 126-137. (in Russian). DOI: https://doi.org/10.15688/jvolsu4.2018.1.12
\end{abstract}




\title{
ВОССТАНОВЛЕНИЕ СТАЛИНГРАДСКОЙ ОБЛАСТИ: СПЕЦИФИКА ИСПОЛЬЗОВАНИЯ ГОСУДАРСТВЕННО-ОРГАНИЗАЦИОННЫХ, ФИНАНСОВО-КРЕДИТНЫХ РЕСУРСОВ СССР В 1943-1944 ГОДАХ
}

\author{
Татьяна Владимировна Лохова \\ Новороссийский филиал Финансового университета при Правительстве Российской Федерации, \\ г. Новороссийск, Российская Федерация
}

\section{Елена Михайловна Малышева}

Адыгейский государственный университет, г. Майкоп, Российская Федерация

\begin{abstract}
Аннотация. Необходимость обращения к историческому опыту Победы в Великой Отечественной войне, анализу основных событийных линий, таких как, например, «коренной перелом» и отдельно Сталинградскаябитва, интересна не только с точки зрения дани Памяти в преддверии юбилейных дат, но и с точки зрения организации беспрецедентных по своим масштабам операций и проектов. Научный интерес представляет исследование технологии управления и специфики дефиниции экономических и социально-политических ресурсов для восстановления разрушенного военными действиями и оккупацией хозяйства СССР, а также перевода его на мирные рельсы.

Данная статья посвящена изучению деятельности кредитных учреждений СССР, которые сыграли значительную роль в восстановлении освобожденных от немецкой оккупации регионов СССР. Практика организации целевых кредитных программ восстановления разрушенного хозяйства СССР в 1943-1944 гг. рассматривается на материалах южного региона России, а именно г. Сталинграда и Сталинградской области. Авторы анализируют опыт взаимодействия банковской сферы СССР в части выделения ссуд населению страны с целью скорейшего восстановления разрушенного хозяйства региона, а также реализации социальной государственной политики защиты различных категорий населения.

Восстановление Сталинградской области рассмотрено сквозь призму выявления специфики использования государственно-организационных, финансово-кредитных и морально-патриотических ресурсов СССР в 1943-1944 годах. Для преодоления последствий вражеской оккупации потребовались дополнительные бюджетные ассигнования, которые были направлены на первоочередное восстановление ряда разрушенных, но крайне необходимых для экономики предприятий, на реэвакуацию части промышленного оборудования, возвращение поголовья эвакуированного скота, возврат специалистов, их бытовое устройство, на создание производственной инфраструктуры, восстановление жилищного фонда города и деревни и т. п. Методы и средства реализации поставленных целей, например, восстановления разрушенного хозяйства в постоккупационный период, были самыми разнообразными: от четко организованной линии властных структур до колоссального, порой жертвенного, участия населения страны в восстановительных мероприятиях в форме всенародной помощи, участия в военных займах, налоговых выплат. Учитывая хроническую нехватку бюджетных средств, правительство страны надеялось на максимальное использование инициативы местных управленческих кадров по изысканию внутренних резервов освобожденных регионов и территорий, находящихся в глубоком тылу. Возрождение экономической, социальной и духовной сфер в освобожденных районах являлось общенациональной проблемой, реализация которой сплачивала народы страны.

Т.В. Лохова, рассматривая цели денежной и кредитной политики, показала положительный опыт функционирования Госбанка и Сельхозбанка СССР, которые в условиях мобилизационной экономики объединили цели кредитно-денежной политики. Е.М. Малышевой проведен историографический обзор научных исследований современности по выявлению специфики деятельности органов советской власти в критических условиях восстановления страны после освобождения от немецко-фашистской оккупации.

Ключевые слова: Великая Отечественная война, восстановление разрушенного хозяйства, кредитные программы, ссуда, займ, Госбанк СССР, Сельхозбанк СССР, Сталинград, Сталинградская область.

Цитирование. Лохова Т. В., Малышева Е. М. Восстановление Сталинградской области: специфика использования государственно-организационных, финансово-кредитных ресурсов СССР в 1943-1944 годах // Вестник Волгоградского государственного университета. Серия 4, История. Регионоведение. Международные отношения. - 2018. - Т. 23, № 1. -C. 126-137. - DOI: https://doi.org/10.15688/jvolsu4.2018.1.12
\end{abstract}


Проблемы Великой Отечественной войны и связанные с ней социальные, экономические, финансовые, моральные, психологические, демографические и иные процессы, анализ деятельности органов советской власти по поиску выхода из критических ситуаций становились предметом осмысления на протяжении более 70 лет после окончания войны. На всех этапах формирования историографии Великой Отечественной войны прогрессивные профессиональные историки по мере возможности стремились давать объективную оценку событиям военного времени, вводили в научный оборот новые доступные документы и материалы, придавая большое значение историографическому анализу опубликованных трудов по истории войны. До 1990-х гг. историческая наука имела четко определенный историко-партийный, политический характер, определивший тематическую диспропорцию в исследовании проблем военного периода, образовались так называемые «белые пятна». Наиболее изученными стали проблемы, связанные с участием и ролью в боевых действиях и тылу таких социальных групп общества, как рабочие, крестьяне, интеллигенция, женщины, молодежь. Целый ряд важных социальных проблем исследователи вынуждены были обходить в силу их запретного характера и засекреченности документов. Среди подобных «закрытых» для исследования тем оказались медико-санитарные последствия войны, материально-бытовое положение и настроения граждан, влияние конфессий, репрессивно-карательная деятельность НКВД, депортации, коллаборационизм, дезертирство, военнопленные и т. д.

Неоднозначные процессы эволюции власти на пути к победе, регулируемые ею консолидированные усилия по сплоченности общества в возрождении промышленности и транспорта, а также восстановление села после освобождения от фашистской оккупации, деформации национальной политики СССР депортации военных лет становятся востребованными темами научных исследований. В новейшей историографии войны отмечается всплеск разноплановых научных изысканий по всем периодам войны. Интерес ученых привлекают не только проблемы освещения боевых действий, взаимодействия фронта и тыла, но и тематика повседневной жизни населения, стратегий выживания отдельных социальных групп в этот период, где отмечается снижение жизненного уровня подавляющей части граждан, существенное ухудшение условий их жизни, здоровья, питания и жилья [1]. Как отмечает Е.М. Малышева, в геополитических реалиях XXI в. как никогда востребован осознанный всеми гражданами общенациональный интерес и нравственная основа, которые достигаются через возможности государства и его институтов. Самым глубоким и сильным источником победы, нравственным стержнем социума был патриотизм, исконно присущая россиянам любовь к своему Отечеству, которая помогла не только выдержать все трудности военного лихолетья, но консолидироваться и победить [7, с. 182].

Тем не менее, несмотря на разнообразие сюжетов социальной истории военного периода, вне поля зрения ученых остаются, как отмечает в своей работе Н.В. Кузнецова, наиболее острые проблемы промышленного строительства в стране, комплекс вопросов производственной деятельности предприятий; не изучены жилищно-бытовые условия советских граждан. «Помимо специальных исследований, историкам предстоит создать фундаментальные обобщающие работы о послевоенном подвиге советского народа, в короткий срок превратившего полуразрушенную страну в сверхдержаву» [2, с. 150]. Вторая мировая война в целом характеризовалась стремительным ростом финансовых расходов на военные цели. Если в Первую мировую войну совокупные военные расходы из бюджетов государств составили 208 млрд долларов, то в годы Второй мировой войны они достигли 1 трлн 117 млрд долларов (695 млрд долларов израсходовали страны антигитлеровской коалиции и 422 млрд долларов - Германия с союзниками). В национальном доходе США доля военных расходов составила $43,4 \%$, Англии $-55,7 \%$, Германии - 67,8 \%, Японии 49,7 \%. Прямые военные расходы СССР составили 55 \% национального дохода. Значительную часть военных издержек составили потери, вызванные разрушениями и уничтожением материальных ценностей. Особый урон был нанесен Советскому Союзу. Фашисты подвергли варварскому разграблению 
временно оккупированные области СССР. Огромным был ущерб от прямого уничтожения и разрушения материальных ценностей на территории нашей страны: он составил почти $41 \%$ всех потерь участвовавших в войне стран [6, с. 69].

Необходимость обращения к историческому опыту победы в Великой Отечественной войне, анализу основных событийных линий, таких как, например, «коренной перелом» и отдельно Сталинградская битва, интересна с точки зрения не только дани памяти в преддверии юбилейных дат, но и организации беспрецедентных по своим масштабам операций и проектов. Научный интерес представляет исследование технологии управления и специфики дефиниции экономических и социально-политических ресурсов для восстановления разрушенного военными действиями и оккупацией хозяйства СССР, а также перевода его на мирные рельсы. Практическую значимость имеет также изучение механизма эффективного устройства модернизационных процессов, позволивших в сжатые сроки при минимальных финансовых и материальных ресурсах достичь значительных позитивных результатов.

Таким ключевым проблемам, как Сталинградская битва, восстановление Сталинграда после глобальных разрушений, посвящена обширная историография. Отметим, что только в Волгоградском государственном университете сложился ряд научных школ и направлений, уделяющих большое внимание данной проблематике [12, с. 143]. Творческими научными коллективами историков ведется работа по нескольким направлениям. Важнейшим из них стала публикация сборников документов, посвященных деятельности Сталинградского городского комитета обороны, участию народного ополчения в Сталинградской битве, деятельности Сталинградской группы войск в 1943 г., восстановлению Сталинграда, в том числе и военнопленными. Эти публикации дают возможность всесторонне и объективно представить политические и социально-экономические процессы, происходившие в Сталинградской области в 1941-1953 гг.; оценить деятельность административных, партийных, чрезвычайных и военных органов в этот период. Восстановление Сталинградс- кой области интересно для нас с точки зрения анализа организации и использования государственно-организационных, финансово-кредитных ресурсов СССР в 1943-1944 годах.

Контрнаступление советских войск под Сталинградом положило начало массовому изгнанию врага с оккупированных территорий. Военные действия и вражеская оккупация нанесли огромный урон экономике Юга России, составивший более 50 млрд руб. [13, c. 23]. Эту сумму нельзя считать окончательной, поскольку необходимо приплюсовать расходы государства на строительство и демонтаж оборонительных сооружений, эвакуацию, реэвакуацию и т. д. Для преодоления последствий вражеской оккупации потребовались дополнительные бюджетные ассигнования, которые были направлены на первоочередное восстановление ряда разрушенных, но крайне необходимых для экономики предприятий, на реэвакуацию части промышленного оборудования, возвращение поголовья эвакуированного скота, возврат специалистов, их бытовое устройство, на создание производственной инфраструктуры, восстановление жилищного фонда города и древни и т. п. Методы и средства реализации поставленных целей, например, восстановления разрушенного хозяйства в постоккупационный период, были самыми разнообразными: от четко организованной линии властных структур до колоссального, порой жертвенного, участия населения страны в восстановительных мероприятиях в форме всенародной помощи, участия в военных займах, налоговых выплат. В ряде научных работ Т.В. Лоховой сделана попытка рассмотреть процесс восстановления разрушенного хозяйства через призму анализа использования властными структурами финансово-кредитных механизмов и инструментов, а также претворения в жизнь кредитных программ на освобожденных от немецко-фашистской оккупации территориях СССР в 1943-1945 гг. [3-5]. При этом автор анализирует опыт взаимодействия банковской сферы СССР в части выделения ссуд городам и предприятиям, колхозам и колхозному населению с целью скорейшего восстановления сельскохозяйственного потенциала региона, а также реализации социальной государственной политики защиты различных категорий населения. 
Пристального внимания при анализе процесса реализации кредитных программ восстановления разрушенного хозяйственного и жилищного фонда заслуживает изучение механизма осуществления советской системы управления. Большинство современных исследователей советского периода склонны видеть в советской системе сталинского периода, в том числе в 1940-х гг., исключительно «жесткую вертикаль» власти с четким исполнением идущих сверху приказов [15]. О.В. Хлевнюк в своем исследовании отмечает, что «централизация военного времени парадоксальным образом совмещалась с некоторым расширением оперативной самостоятельности управленцев всех уровней» [14, с. 455]. Мы солидарны с этим мнением, поскольку проведенный анализ механизма осуществления кредитования населения, колхозов и промышленных предприятий выявил не как исключение, a, скорее, как правило персонификацию принятия решений, личную ответственность и взаимовыручку, стремление в кратчайшие сроки выполнить поставленную задачу.

В целом государственная денежно-кредитная политика в условиях мобилизационной экономики во многом базируется на использовании стимулирующей функции кредита, через которую осуществляется распределение ресурсов для противодействия угрозам существования страны как целостной системы. Причем именно практика организации целевых кредитных программ восстановления разрушенного хозяйства СССР в 1943-1944 гг. в постоккупационный период г. Сталинграда и Сталинградской области дала стимулирующий импульс для скорейшего восстановления разрушенного хозяйства региона, а также реализации социальной государственной политики защиты различных категорий населения. Положительный опыт взаимодействия банковской сферы СССР в части выделения ссуд населению страны наглядно показал, что возможно согласование между государственными интересами и макроэкономическими целями, с одной стороны, и частными интересами населения - с другой.

После освобождения оккупированных немецко-фашистскими захватчиками территорий Сталинградской области первоочередной задачей было восстановление разрушенных хозяйств как в городах, так и в сельском секторе региона (задачи восстановления были сформулированы в постановлении СНК СССР и ЦК ВКП(б) от 21 августа 1943 г. «О неотложных мерах по восстановлению хозяйства в районах, освобожденных от немецкой оккупации»). Еще ранее ряд постановлений ГКО и СНК СССР регламентировал контроль восстановления разрушенного хозяйства отдельных регионов СССР, в частности, методика государственно-организационного регулирования восстановления разрушенного хозяйства Сталинградской области и г. Сталинграда нашла отражение в следующих документах:

- Постановление ГКО № 2895 от 14.021943 г. «О восстановлении завода № 91 Наркомхимпрома в г. Сталинграде» (контроль за выполнением был возложен на т. Берия Л.П.);

- Постановление СНК СССР № 268 от 13.031943 г. «О создании треста совхозов в Сталинградской области» (контроль за выполнением был возложен на т. Андреева А.А.);

- Постановление ГКО № 3014 от 09.031943 г. «О частичном восстановлении электростанций, сетей и подстанций в г.г. Грозном, Оржоникидзе, Сталинграде и Воронеже» (контроль за выполнением был возложен на т. Маленкова Г.М.);

- Постановление ГКО № 3117 от 04.041943 г. «О первоочередных мероприятиях по восстановлении хозяйства Сталинграда и Сталинградской оюласти» (контроль за выполнением был возложен на т.т. Вознесенского Н.А. и Косыгина А.Н.);

- Постановление ГКО № 3230 от 22.041943 г. «О восстановлении Сталинградского тракторного завода и завода № 264 Наркомтанкопрома» (контроль за выполнением был возложен на т. Берия Л.П.);

- Постановление ГКО № 3356 от 12.051943 г. «О работах по восстановлению Сталинградского гидролизного завода Главлесоспирта (контроль за выполнением был возложен на т. Микояна А.И. - T. Л., E. M.) и Сталинградского лесокомбината им. Куйбышева (контроль за выполнением был возложен на т. Косыгина А.Н. - Т. Л., Е. М.)»;

- Постановление СНК СССР № 579-179 от 22.051943 г. «О восстановлении жилищнокоммунального хозяйства г. Сталинграда» 
(контроль за выполнением был возложен на т. Косыгина А.Н.);

- Постановление СНК СССР № 656 от 12.061943 г. «О мероприятиях по восстановлению Сталинградских лесозаводов Наркомлеса СССР» (контроль за выполнением был возложен на т. Косыгина А.Н.);

- Постановление ГКО № 3582 от 15.061943 г. «О восстановлении в г. Сталинграде завода № 221 Наркомата Вооружения» (контроль за выполнением был возложен на т. Берия Л.П.);

- Постановление ГКО № 3649 от 26.061943 г. «О выделении металлорежущих станков Сталинградскому тракторному заводу» (контроль за выполнением был возложен на т. Берия Л.П.);

- Постановление ГКО № 3849 от 02.081943 г. «Об обеспечении выполнения решения ГКО-3376 от 15.05.43 г. “О восстановлении Сталинградского металлургического завода “Красный Октябрь”» (контроль за выполнением был возложен на т. Маленкова Г.М.) [8, л. 14-21].

Спектр обозначенных первоочередных задач восстановления разрушенного хозяйства Сталинграда и Сталинградской области только в эти полгода 1943 г. года позволяет сделать вывод, что ГКО СССР требовал от властных структур оперативных и действенных мер по организации восстановительного процесса. Возрождение разоренных войной предприятий, социально-бытовой сферы давало возможность оперативного снижения уровня безработицы и трудоустройства населения освобожденных районов, мобилизации его усилий на изготовление разнообразной продукции, пользовавшейся спросом и фронта, и тыла. ГКО СССР, принимая серию постановлений по восстановлению разрушенного хозяйства освобожденных от оккупации территорий, централизованно и оперативно осуществлял контроль за выделением средств из госбюджета. Задачи ликвидации последствий оккупации требовали немедленного восстановления не только всего производственного процесса народного хозяйства, но и материально-бытовой базы жителей региона. Созданный Комитет при Совете народных комиссаров СССР по восстановлению хозяйства в районах, освобожденных от немецкой оккупации, четко разграничивал круг организационных и руководящих полномочий между членами комитета. Так, например, повесткой дня заседания Комитета от 08.091943 г. конкретно определялись ответственные за выполнение сроков выполнения Постановления СНК СССР и ЦК ВКП(б) от 21.081943 г. - «тт. Маленков, Берия, Микоян, Вознесенский»; за план восстановления и постройки новых жилых домов и местных строительных материалов в освобожденных районах - т. Вознесенский [8, л. 204].

Задача восстановления освобожденных территорий была чрезвычайно сложной, поскольку порой степень разрушения населенного пункта была не частичной, а сплошной (до почти 100 \% разрушения в некоторых населенных пунктах). Восстановление государственных, ведомственных зданий требовало больших материальных затрат и значительного времени, и тем не менее восстановление жилого фонда являлось первоочередным. Восстановительные работы после освобождения Сталинграда и территорий трех районов Сталинградской области позволило уже к 1 сентября 1943 г. восстановить и вновь построить 3535 жилых домов в г. Сталинграде и 201 - в сельской местности. Таким образом, в Сталинграде было введено в эксплуатацию 159640 кв. м жилой площади. Число вселенных людей в восстановленные и вновь построенные дома в Сталинграде составило 44314 человек, в сельской местности трех районов области 766 [8, л. 48]. Этого количества домов и жилой площади категорически не хватало. Так, в Справке о восстановленных и вновь построенных жилых домах Н.А. Вознесенского и А.Н. Косыгина от 7 сентября 1943 г. указывалось, что в Сталинградской области проживают в землянках и разрушенных домах на 01.091943 г. в сельских местностях 14648 человек и в Сталинграде - 30000 человек [8, л. 51]. Предлагалось в течение кратчайшего времени (двух месяцев) восстановить в сельской местности 2212 домов и в Сталинграде - 5000 индивидуальных домов, в том числе за первый месяц планировалось восстановить около 40 \% домов как в городе, так и в деревне, в которые предполагалось переселить из землянок 5000 человек из сельской местности и 12000 человек - в г. Сталинграде [8, л. 51]. В Отчете о ходе выполнения постанов- 
ления Сталинградского областного комитета ВКП(б) № 076 от 11 сентября 1943 г. отмечалось, что по освобожденным районам от немецкой оккупации из подлежащих восстановлению 2012 индивидуальных домов по состоянию на 10 сентября всего восстановлено 965 домов с жилой площадью 19300 кв. м, расселено в них, по неполным данным, до 6000 человек. По городу Сталинграду из подлежащих к постройке вновь 5000 индивидуальных домов на 10 сентября выстроено 2300 домов с жилой площадью 303884 кв. м, а всего выстроено и восстановлено 4846 домиков с площадью 88951 кв. м. В процессе восстановления и строительства находилось 3539 домиков с площадью 36385 кв. м. На 10 сентября 1943 г. Коммунальным банком было отпущено индивидуальным застройщикам г. Сталинграда 493 тыс. руб. [10, л. 183]. Для обеспечения стеновым материалом индивидуального строительства и алебастром было решено построить в г. Камышине алебастровый завод и заводы по выработке глинита и блоков из него (в Красноармейске и Ольховке) [9, л. 225].

Низкие темпы строительства объяснялись объективными причинами - «совершенно неудовлетворительное обеспечение лесом, стеклом и кровельными материалами. Из отпущенных Совнаркомом СССР 30 тыс. кубометров леса для Облисполкомовского строительства до сего времени от Главснаблеса ничего не получено» $[10$, л. 182$]$. Для удовлетворения нужд рабочих-застройщиков индивидуального строительства стройматериалами в Сталинграде было открыто 5 магазинов по розничной продаже строительных материалов [10, л. 182].

Решить проблемы восстановления было невозможно без привлечения мощных финансовых потоков и реализации программ кредитования колхозов и сельского населения. Несмотря на сложные условия, на протяжении всего периода Великой Отечественной войны оставались неизменными основные принципы банковского кредитования, такие как социально-экономическая помощь населению страны, развитие кредитования колхозам, нацеленность на результат, организация и внедрение целевых программ [3, с. 339]. Однако доступ к дешевым кредитным ресурсам, обеспечи- ваемый банковской сферой СССР, вовсе не давал пропорциональный рост макроэкономических показателей. В первые два года происходило уменьшение материальных запасов и резервов в народном хозяйстве, что привело к некоторому сокращению общего объема краткосрочных кредитных операций Госбанка СССР при росте кредитов предприятий военной промышленности, поскольку через кредитную систему перераспределялись основные средства по плану, в зависимости от складывающейся военной обстановки. Банковская система СССР еще с мая 1932 г. разграничивала функции между Госбанком и банками долгосрочных вложений (Промбанком, Сельхозбанком, Всекобанком и Цекомбанком), поскольку цель денежной политики состоит в исключении дисбаланса (избытка или дефицита) денежной массы относительно потребностей экономики, в то время как целью кредитной политики является регулирование доступности кредита.

Однако в условиях мобилизационной экономики соединение целей денежной и кредитной политики чрезвычайно важно для оперативности выбора инструментов денежно-кредитной политики государства в целом, а также ее параметров и прогнозирования возможных результатов. Поэтому главную роль в осуществлении денежной и кредитной политики в СССР играл Госбанк, который осуществлял ряд соответствующих мероприятий: усиление кредитной помощи предприятиям оборонного значения; налаживание кредитования и расчетов для предприятий, эвакуированных в восточные регионы страны (им выдавались ссуды на покрытие затрат, связанных с эвакуацией; они получали отсрочку в погашении долгов на сроки до полного восстановления деятельности на новом месте, что способствовало быстрому возобновлению производства); предоставление помощи и отсрочка долгов предприятиям на освобожденных территориях; проведение льготного режима кредитования отделам рабочего снабжения и подсобным хозяйствам при промышленных предприятиях; выдача кредита на развертывание производства товаров широкого потребления, специальных кредитов предприятиям, переходившим на выпуск мирной продукции; упорядочение системы расчетов, которая укрепляла 
действующий хозрасчет, внутрипромышленные накопления [11, с. 111].

В функционале Сельхозбанка СССР находились вопросы кредитования восстановления колхозов и непосредственное жилищное строительство для населения села. Причем в 1943-1945 гг. Сельхозбанк СССР и его филиалы занимались организацией обеспечения целевых кредитных программ восстановления разрушенного хозяйства путем выдачи ссуд колхозам и населению. Целевые кредитные программы для колхозов Сталинградской области, как и для других регионов СССР, предполагали выдачу ссудных сумм для восстановления разрушенных построек, для восстановления животноводства.

Кредитование сельского населения Сталинградской области предполагало реализацию ссуд сразу по нескольким направлениям:

a) кредитование на реализацию плана восстановления хозяйства (восстановление домовладения, жилищное строительство, строительство хозяйственных построек, надворных построек, восстановление животноводческого индивидуального хозяйства, на покупку скота, хозобзаведение, восстановление рыбного домашнего промысла и т. п.);

б) кредитование социально незащищенной и нуждающейся категории населения (инвалиды войны, семьи погибших воинов);

в) кредитование участников войны и членов их семей (семьи фронтовиков, семьи партизан, демобилизованные и т. п.);

г) кредитование представителей отдельных профессий (сельские врачи, фельдшеры, учителя и т. д.).

В декабре 1943 г. по всем филиалам Сельхозбанка и отделениям Госбанка в Сталинградской области, выполняющим операции Сельхозбанка, были разосланы циркулярные письма о разрешении за счет открытого кредита на индивидуальное жилстроительство колхозников кредитовать также рабочих и служащих всех ведомств, в первую очередь инвалидов Отечественной войны, проживающих в сельской местности. Кредитоваться могли также и единоличники, пострадавшие от оккупации, на восстановление и строительство домов и надворных построек. Гарантийные обязательства для этой категории заемщиков не отбирались, формировались списки и зак- лючения учреждений и предприятий через решение райисполкома в каждом отдельном случае. Рабочим и служащим совхозов, МТС, предприятий кредит выдавался под обязательства предприятий; специалистам райзо, врачам, учителям - под их личные обязательства (причем кредитование рабочих и служащих производилось при непременном условии предоставления справки о наделении их земельным участком). Условия кредита были такими же, как и у колхозников: до 10000 руб. на каждое хозяйство сроком до 7 лет. На покупку готовых домов кредит не выдавался по всем категориям индивидуальных заемщиков, поскольку основной целью предоставления кредита должно было являться расширение жилой площади [5, с. 193]. Начальный срок погашения ссуд указан был четко в правилах кредитования: в первом квартале по окончании строительства. Если срок строительства указывался на один год, то первый срок платежа предусматривался на 14-15-й месяц (по соглашению с заемщиком), если же срок восстановления был шестимесячным, то первый срок платежа должен был поступить не позднее 9-го месяца и т. д.

Еще раз подчеркнем, что восстановление началось в условиях продолжающейся войны, а потому суммы, выделяемые регионам для кредитования населения, Сталинградской области в том числе, хотя и были существенными, в полной мере не могли по объективным причинам удовлетворить потребности региона. Имевшие место проблемы кризисов в снабжении освобожденных территорий, наличие достаточно острого дефицита необходимых первоочередных товаров, нередко встречавшихся злоупотреблений чиновниками отражались на общественных настроениях. Они перерастали в дискуссии о социальной справедливости, что находило отражение в неоднократных письмах-обращениях граждан в органы государственной власти и средства массовой информации. Учитывая хроническую нехватку бюджетных средств, правительство страны надеялось на максимальное использование инициативы местных управленческих кадров по изысканию внутренних резервов освобожденных регионов и территорий, находящихся в глубоком тылу. Нуждающихся в кредитах было больше, чем возможно 
было обеспечить в рамках открытых лимитов по регионам, и зачастую уже к осени финансового года распределенные кредитные суммы были полностью выбраны [13, с. 24]. Госплан СССР и Госбанк СССР после обращения региональных властей увеличивали сумму кредитования для отдельных категорий населения, например, для социально незащищенных и нуждающихся категорий населения инвалидов войны, членов семей погибших воинов. Отделение Сталинградского Сельхозбанка в этом случае рассматривало правлением заявление каждого нуждающегося и выносило персонифицированное решение о выдаче ссуды, ее размера и срока выплаты $[9$, л. 25, 36, 78].

Восстановление Сталинграда и Сталинградской области, помимо использования мощного финансово-кредитного и государственноорганизационного ресурса, невозможно было и без колоссального подъема морально-патриотических настроений среди населения всей страны, готовой реально участвовать в возрождении города, который олицетворял собой символ стойкости и мужества. В СССР развернулось массовое шефское движение регионов, не пострадавших от фашисткой оккупации. Области и края брали на себя обязательства помощи финансовым ресурсом, поставкой рабочих кадров, различными предметами быта и инвентарем, стройматериалами помогать не только закрепленному за ними региону, но и дополнительно Сталинграду и Сталинградской области. Например, Узбекская ССР в качестве шефской помощи была закреплена за Курской, Воронежской и Харьковской областями, но при этом помощь в Сталинград направлялась вагонами. Именно такими единицами измерения пользовались при составлении справок-отчетов об оказанной помощи при обсуждении на заседаниях областных и краевых властей. За Куйбышевской областью были закреплены Сталинградская область и Донбасс. Уже в ноябре 1943 г. Куйбышевской областью в качестве шефской помощи Сталинграду было отправлено 180 вагонов (по 20 вагонов алебастра и красного кирпича, по 10 вагонов гудрона, толя и рубероида, пиломатериалов, 15 вагонов других стройматериалов, 4 вагона оконных рам и дверей и др.) [9, л. 29]. А на 10 декабря 1943 г. отмечалось, что жителями Куйбышевской области собраны средства свыше 3,5 млн рублей, из которых для Сталинграда и Сталинградской области было отписано 3016000 руб.; послано на восстановительные работы в Сталинград 911 человек [9, л. 55-58]. В справке Кировской области отмечалось, что организациями, предприятиями и жителями области было собрано для восстановления Сталинграда 3624683 руб., отправлены также «вагонами» лесоматериалы, промышленные и хозяйственные металлоизделия, электрооборудование, кабельное оборудование и др. [9, л. 61]. Эти примеры демонстрируют лишь малую толику той помощи, которую оказывали регионы СССР (области и республики) в деле восстановления Сталинграда и Сталинградской области.

Подводя итоги, необходимо резюмировать, что финансово-кредитные учреждения СССР сыграли значительную роль в восстановлении освобожденных от немецкой оккупации регионов СССР. Организация целевых кредитных программ восстановления разрушенного хозяйства СССР в 1943-1944 гг. на Юге страны явилась своевременной мерой возрождения экономики страны после катастрофических разрушений военных действий, военных сражений и оккупации. Анализируемый в статье опыт взаимодействия банковской сферы СССР в части выделения ссуд населению страны с целью скорейшего восстановления разрушенного хозяйства региона, а также реализации социальной государственной политики защиты различных категорий населения позволил сделать выводы о целесообразности и действенности подобных программ как ресурса восстановления и развития экономики СССР. Восстановление Сталинградской области в 1943-1944 гг. невозможно было осуществить без привлечения государственно-организационных, финансово-кредитных и морально-патриотических ресурсов, в связи с чем потребовались дополнительные бюджетные ассигнования, которые были направлены на первоочередное восстановление ряда разрушенных, но крайне необходимых для экономики предприятий, на реэвакуацию части промышленного оборудования, возвращение поголовья эвакуированного скота, возврат специалистов, их бытовое устройство, на 
создание производственной инфраструктуры, отстраивание жилищного фонда города и деревни и т. п. Методы и средства реализации поставленных целей, например, восстановления разрушенного хозяйства в постоккупационный период, были самыми разнообразными: от четко организованной линии властных структур до колоссального, порой жертвенного, участия населения страны в восстановительных мероприятиях в форме всенародной помощи, участия в военных займах, налоговых выплат.

\section{СПИСОК ЛИТЕРАТУРЫ}

1. Кринко, Е. Ф. Современная российская историография Великой Отечественной войны: итоги двух десятилетий / Е. Ф Кринко // Былые годы. 2009. - № 4 (14). - Электрон. текстовые дан. - Режим доступа: http://bg.sutr.ru/journals_n/1317458120.pdf (дата обращения 12.02.2017). - Загл. с экрана.

2. Кузнецова, Н. В. Отечественная историография об экономических и социальных проблемах послевоенного восстановления и развития страны в 1945-1953 гг. / Н. В. Кузнецова // Вестник Волгоградского государственного университета. Серия 4 , История. Регионоведение. Международные отношения. -2005 . - № 10. - С. 141-153.

3. Лохова, Т. В. История организации Сельхозбанком СССР целевых кредитных программ восстановления разрушенного хозяйства Краснодарского края в 1943-1945 гг. / Т. В. Лохова // Юг России и сопредельные страны в войнах и вооруженных конфликтах : материалы Всерос. науч. конф. с междунар. участием. - Ростов н/Д : ФАНО : ЮНЦ РАН : ИСЭГИ, 2016. - С. 337-344.

4. Лохова, Т. В. Практика организации целевых кредитных программ восстановления разрушенного колхозного хозяйства в 1943-1945 гг. (на материалах Краснодарского края) / Т. В. Лохова // Военная история России: проблемы, поиски, решения : материалы III Междун. науч. конф., посвящ. 160 -летию окончания Крымской войны 18531856 гг. В 2 ч. Ч. 2. - Волгоград : Изд-во ВолГУ, 2016. C. 253-259.

5. Лохова, Т. В. Реализация кредитных программ восстановления разрушенного хозяйства краснодарского края (1943-1945 гг.) / Т. В. Лохова // Память и время: влияние войн и вооруженных конфликтов XX в. на российское общество : сб. ст. Междунар. науч. конф. - Пенза : Изд-во ПГУ, 2016. C. 190-197.

6. Малышева, Е. М. Мировые войны и локальные военные конфликты в истории: последствия, уроки / Е. М. Малышева // Вестник Адыгейского государственного университета. - 2005. - № 1(16). C. 69-78.

7. Малышева, Е. М. Социоэтнические компоненты массового общественного сознания в годы Великой Отечественной войны: патриотизм, интернационализм и коллаборационизм / Е. М. Малышева // Вестник Адыгейского государственного университета. - 2001. - № 4. - С. 163-185.

8. Материалы к протоколу № 3 заседания Комитета при СНК СССР по восстановлению хозяйства в районах, освобожденных от немецкой оккупации // Государственный архив Российской Федерации (ГАРФ). - Ф. Р-9504. - Оп. 1. - Д. 1. - 204 л.

9. Отчеты наркоматов, ведомств областей, краев и республик по выполнению Постановлению СНК СССР и ЦК ВКП(б) // ГАРФ. - Ф. Р-9504. Оп. 1. - Д. 21. -234 л.

10. Отчеты наркоматов, ведомств областей, краев и республик по выполнению Постановления Совет Народных Комиссаров СССР и ЦК ВКП(б) // ГАРФ. - Ф. Р-9504. - Оп. 1. - Д. 22. - 220 л.

11. Петренко, В. А. Денежно-кредитная политика государства в годы Великой Отечественной войны / В. А. Петренко, М. В. Павлова // Вестник КамчатГТУ. -2016 . - № 35. - С. 110-112.

12. Редькина, О. Ю. Изучение истории Сталинградской битвы и восстановления Сталинграда в Волгоградском государственном университете / О. Ю. Редькина // Вестник Волгоградского государственного университета. Серия 4, История. Регионоведение. Международные отношения. 2013. - № 1. - C. 143-148. - DOI: https://doi.org/ 10.15688/jvolsu4.2013.1.23.

13. Селюнина, Н. В. Экономика Юга России в 1941-1945 гг. / Н. В. Селюнина, Е. М. Малышева // Научная мысль Кавказа. - 2005. - № 1. - С. 18-27.

14. Хлевнюк, О. В. Хозяин. Сталин и утверждение сталинской диктатуры / О. В. Хлевнюк. - М. : РОССПЭН, 2010. $-479 \mathrm{c}$.

15. Черепанов, В. В. Власть и война: Сталинский механизм государственного управления в Великой Отечественной войне / В. В. Черепанов. - М. : Известия, 2006. - 496 с.

\section{REFERENCES}

1. Krinko E.F. Sovremennaya rossiyskaya istoriografiya Velikoy Otechestvennoy voyny: itogi dvukh desyatiletiy [Modern Russian Historiography of the Great Patriotic War: Results of the Last Two Decades]. Bylye gody, 2009, vol. 4(14). URL: http://bg.sutr.ru/journals_n/ 1317458120.pdf(accessed February 12, 2017).

2. Kuznetsova N.V. Otechestvennaya istoriografiya ob ekonomicheskikh i sotsialnykh problemakh 
poslevoennogo vosstanovleniya i razvitiya strany $\mathrm{v}$ 1945-1953 gg. [Russian Historiography of Economic and Social Issues of Post-War Restoration and Development of the Country in 1945-1953]. Vestnik Volgogradskogo gosudarstvennogo universiteta. Seriya 4, Istoriya. Regionovedenie. Mezhdunarodnye otnosheniya [Science Journal of Volgograd State University. History. Area Studies. International Relations], 2005, no. 10, pp. 141-153.

3. Lokhova T.V. Istoriya organizatsii Selkhozbankom SSSR tselevykh kreditnykh programm vosstanovleniya razrushennogo khozyaystva Krasnodarskogo kraya v 1943-1945 gg. [History of Working Out Loan Programs by the USSR Agricultural Bank for Restoring the Krasnodarskiy Krai in 19431945]. Yug Rossii $i$ sopredelnye strany $v$ voynakh $i$ vooruzhennykh konfliktakh: materialy Vseros. nauch. konf. s mezhdunar. uchastiem [The South of Russia and Adjacent Countries in Wars and International Conflicts: Proceedings of the All-Russian Conference with International Participation]. Rostov-on-Don, FANO; YuNTs RAN; ISEGI Publ., 2016, pp. 337-344.

4. Lokhova T.V. Praktika organizatsii tselevykh kreditnykh programm vosstanovleniya razrushennogo kolkhoznogo khozyaystva v 1943-1945 gg. (na materialakh Krasnodarskogo kraya) [Practice of Organising Loan Programs for Restoring Agriculture in 1943-1945 (the Case of the Krasnodarskiy Krai)]. Voennaya istoriya Rossii: problemy, poiski, resheniya: materialy III Mezhdun. nauch. konf., posvyashch. 160-letiyu okonchaniya Krymskoy voyny 1853-1856 gg. V 2 ch. Ch. 2 [Military History of Russia: Problems, Searches, Solutions: Proceedings of the $3^{\text {rd }}$ International Academic Conference, Devoted to the $160^{\text {th }}$ Anniversary of the Crimean War of 1853 1856, Volgograd, September 23-24, 2016. In 2 Parts. Part 2]. Volgograd, Izd-vo VolGU, 2016, pp. 253-259.

5. Lokhova T.V. Realizatsiya kreditnykh programm vosstanovleniya razrushennogo khozyaystva krasnodarskogo kraya (1943-1945 gg.) [Implementation of Loan Programs for Restoring Agriculture in the Krasnodar Krai (1943-1945)]. Pamyat i vremya: vliyanie voyn $i$ vooruzhennykh konfliktov $X X$ v. na rossiyskoe obshchestvo: sb. st. Mezhdunar. nauch. konf. [Memory and Time: Influence of Wars and Armed Conflicts of the $20^{\text {th }}$ Century on the Russian Society: Collection of Articles of the International Academic and Practical Conference (Novorossiysk, September 12-15, 2016)]. Penza, Izd-vo PGU, 2016, pp. 190-197.

6. Malysheva E.M. Mirovye voyny i lokalnye voennye konflikty v istorii: posledstviya, uroki [World Wars and Local War Conflicts: Consequences, Lessons]. Vestnik Adygeyskogo gosudarstvennogo universiteta, 2005, vol. 1, no. 16, pp. 69-78.

7. Malysheva E.M. Sotsioetnicheskie komponenty massovogo obshchestvennogo soznaniya $\mathrm{v}$ gody
Velikoy Otechestvennoy voyny: patriotizm, internatsionalizm i kollaboratsionizm [Social and Ethnic Components of Mass Public Mind During the Great Patriotic War: Patriotism, Internationalism and Collaborationism]. Vestnik Adygeyskogo gosudarstvennogo universiteta, 2001, no. 4, pp. 163-185.

8. Materialy $\mathrm{k}$ protokolu № 3 zasedaniya Komiteta pri SNK SSSR po vosstanovleniyu khozyaystva $\mathrm{v}$ rayonakh, osvobozhdennykh ot nemetskoy okkupatsii [Materials of Protocol no. 3 of the Session of the Committee under the Council of People's Commissariat of the USSR on Restoring Agriculture in the Areas Liberated from German Occupation]. Gosudarstvennyy arkhiv Rossiyskoy Federatsii [State archive of Russian Federation], F. R-9504, Op. 1, D. 1.2041.

9. Otchety narkomatov, vedomstv oblastey, kraev i respublik po vypolneniyu Postanovleniyu SNK SSSR i TsK VKP(b) [Reports of People's Commissariats, Departments of Different Regions and Republics on Implementing the Regulation of the Council of People's Commissars of the USSR and Central Committee of the Communist Party of the Soviet Union]. Gosudarstvennyy arkhiv Rossiyskoy Federatsii [State archive of Russian Federation], F. R-9504, Op. 1, D. 21.2341.

10. Otchety narkomatov, vedomstv oblastey, kraev i respublik po vypolneniyu Postanovleniya Soveta Narodnykh Komissarov SSSR i TsK VKP(b) [Reports of People's Commissariats, Departments of Different Regions and Republics on Implementing the Regulation of the Council of People's Commissars of the USSR and Central Committee of the Communist Party of the Soviet Union]. Gosudarstvennyy arkhiv Rossiyskoy Federatsii [State archive of Russian Federation], F. R-9504, Op. 1, D. 22. 2201.

11. Petrenko V. A., Pavlova M. V. Denezhnokreditnaya politika gosudarstva $\mathrm{v}$ gody Velikoy Otechestvennoy voyny [Monetary and Loan Policy of the State During the Great Patriotic War]. Vestnik KamchatGTU, 2016, no. 35, pp. 110-112.

12. Redkina O.U. Izuchenie istorii Stalingradskoy bitvy i vosstanovleniya Stalingrada v Volgogradskom gosudarstvennom universitete [Studying history of the Battle of Stalingrad and restoring Stalingrad at Volgograd State University]. Vestnik Volgogradskogo gosudarstvennogo universiteta. Seriya 4, Istoriya. Regionovedenie. Mezhdunarodnye otnosheniya [Science Journal of Volgograd State University. History. Area Studies. International Relations], 2013, no. 1, pp. 143148. DOI: https://doi.org/10.15688/jvolsu4.2013.1.23.

13. Selyunina N.V., Malysheva E.M. Ekonomika Yuga Rossii v 1941-1945 gg. [Economics of the South of Russia in 1941-1945]. Nauchnaya mysl Kavkaza, 2005, no. 1, pp. 18-27.

14. Khlevnyuk O.V. Khozyain. Stalin $i$ utverzhdenie stalinskoy diktatury [Master. Stalin and 
Approvement of His Dictatorship]. Moscow, ROSSPEN Publ., 2010. $479 \mathrm{p}$.

15. Cherepanov V.V. Vlast y voyna: Stalinskiy mechanizm gosudarstvennogo upravleniya $v$
Velikoy Otechesvennoy voyne [Power and War: Stalin's Mechanism of State Control During the Great Patriotic War]. Moscow, Izvestiya Publ., 2006. $496 \mathrm{p}$.

\section{Information about the Authors}

Tatyana V. Lokhova, Candidate of Sciences (History), Deputy Director for Academic Research, Associate Professor, Department of Informatics, Mathematics and Humanities, Novorossiysk Branch of Financial University under the Government of the Russian Federation, Vidova St., 56, 353907 Novorossiysk, Russian Federation, 324548@mail.ru.https://orcid.org/0000-0002-7097-9846

Elena M. Malysheva, Doctor of Sciences (History), Professor, Department of National History, Historiography, Theory and Methodology of History, Adyghe State University, Pervomayskaya St., 208, 385000 Maikop, Russian Federation, emalysheva@yandex.ru. https://orcid.org/0000-0001-6633-2479

\section{Информация об авторах}

Татьяна Владимировна Лохова, кандидат исторических наук, заместитель директора по научной работе, доцент кафедры информатики, математики и общегуманитарных наук, Новороссийский филиал Финансового университета при Правительстве Российской Федерации, ул. Видова, 56, 353907 г. Новороссийск, Российская Федерация, 324548@mail.ru, https://orcid.org/0000-0002-7097-9846

Елена Михайловна Малышева, доктор исторических наук, профессор кафедры отечественной истории, историографии, теории и методологии истории, Адыгейский государственный университет, ул. Первомайская, 208, 385000 г. Майкоп, Российская Федерация, emalysheva@yandex.ru,https://orcid.org/0000-0001-6633-2479 